Jens Hougaard

\title{
Dansk i historien
}

Der er nogen der mener, at det vigtigste karakteristikum ved historien er, at den uigenkaldeligt er forbi. Det, der er sket $i$ fortiden, kan ikke gøres om. Det historiske fremstår som uforanderligt og upåvirkeligt. Det historiskes særlige fascination ligger derfor $i$, at det er absolut bindende, og at enhver $i$ sine handlinger og tolkninger, omend det kan være $\mathrm{i}$ beskedent omfang, skaber historie. Der er noget beroligende i, at sket er sket, og ikke står til at ændre. Uigenkaldeligheden skulle være det, der giver vores liv tyngde, netop uigenkaldeligheden sætter enhver gøren og laden på spidsen. Nu kunne man selvfølgelig lægge vægt på, at der er andre ting der er lige så væsentlige som den enkelte handling, og altså opfatte historien mere omfattende, som det der er rammen for udfoldelsen i historien og som man selv handler forandrende ind i. Men ligemeget hvordan man forholder sig til det problem, kan der vel stort set blive enighed om, at både Kingo og Vilhelm Andersen er afgået ved døden, hvad der naturligvis ikke skal forhindre mig, og heller ikke har forhindret andre $\mathrm{i}$ at mane deres ånder frem. Er historien $\mathrm{i}$ en vis objektiv forstand færdig og afsluttet fortid, så er den $i$ en anden forstand stadig levende og eksisterer $i$ en lang række forskellige udgaver, der har stor betydning for vores handlinger nu.

Der var engang, da historien begyndte med Kristi fødsel, men i Danmark har det været sådan i de sidste par generationer, at i hvert fald den litterære historie begyndte ved romantikken og 
urhistorien omkring 1720. Naturligvis er det ikke sådan, at man ikke var klar over, at der var en tid før romantikken, men den rigtige historie, historien på en bestemt måde begyndte med romantikken. Sådan er det ikke helt længere.

1.

Knæsættelsen af romantikken som altings mål hører ikke romantikken selv til, men er en opfattelse som vokser frem i slutningen af 1800-tallet i kampen mod den radikale del af borgerskabet, især repræsenteret ved Brandesianismen. Den lægger vægt på det »personlige (humane) og folkelige (nationale)* (Vilhelm Andersen) imod det internationalt orienterede borgerskab og imod byradikalismen. At netop romantikken er den historiske periode, der har tiltrukket sig interessen, skyldes den omfattende beskæftigelse med socialisationen, således som den må finde sted på de borgerlige vilkår, hvor den individuelle socialisering er alfa og omega. Den individuelle socialisation har afsat sig som et system af tænkning omkring individualitetens udviklingsmuligheder. Den samfundsmæssige socialisation er blevet formuleret som et spørgsmål om individuation. Dannelsestraditionen har været præget af en typologiserende historisme, der har taget sit udgangspunkt $i$ den individuelle socialisation.

Den tyske og den danske romantik er præget af en borgerlig ideologi, der efter sine sammenbrudte revolutionære bestræbelser har lagt sig i læ af feudalismen. Således blev den historiske tænkning hos borgerskabet overladt til den del, der bedst var i stand til at formulere de borgerlige erfaringer uden konfrontation med det feudale hierarki. Den borgerlige tænkning blev overladt til den statsloyale embedsstand. Den humanistiske forskning har derfor snarere været præget af grundighed og »ærlighed « end af det revolutionære borgerskabs mod til at arbejde sig ud over de gjorte erfaringer. Netop sådan måtte det være, når embedsstanden skulle udarbejde borgerskabets ideologi, men var bundet af sin embedsmæssige loyalitet over for en klassemodstander. Dannelsestraditionen måtte med dette udgangspunkt blive konservativ. 
Med disse historiske fremvækstbetingelser sættes væsentlige dele af de grundlæggende elementer, der også idag er karakteristisk for dannelsestraditionen. Borgerskabets defensive placering i den situation, hvor dannelsestraditionen voksede frem, bet $\varnothing \mathrm{d}$ at enhver reflektion over historien og samfundets udvikling kunne føre frem mod en konflikt med feudale institutioner. Inden for socialisationsteorien lod det sig derimod gøre at udvikle de borgerlige erkendelser uden at støde an, ganske vist med omfattende amputationer af den sociale bevidsthed. Den borgerlige historieskrivning kunne gennem arbejdet med socialisationsteori, der mundede ud i forskellige formuleringer af dannelsesidealet, fastholde sin klassemæssige identitet, men på bekostning af radikaliteten og på bekostning af et udviklet historiesyn.

Historisk var dannelsestraditionen, hvad angår bearbejdningen af historien, en regression bag om de engelske empirister og bag om rationalismen. Hvor disse på et individualistisk grundlag dog udviklede samfundsteorier, der blev forståelsen af individets eksistensbetingelser alene dannelsesteoriens interessefelt. Den var ikke blot individualistisk, men også individualiserende. Det er derfor grundlæggende for dannelsestraditionen, også som vi kender den idag, på tværs af den historiske udvikling at fastholde den individets identitet. I litteraturkritikken viser det sig som en mægtig vilje til at projicere det borgerlige individs eksistensbetingelser ind over alle historiske perioder. (Aage Henriksens læsning af folkeviserne er et eksempel). Dannelsestraditionens interesse for historien er derfor, snarere end en interesse for historien, en interesse $\mathrm{i}$ i historien at påvise de borgerlige eksistensbetingelsers almenhed. Dannelsestraditionerne har således et væsenstræk fælles med al borgerlig tænkning. Den er i sin tendens antihistorisk.

Hos Vilhelm Andersen, dansk litteraturkritisk absolutte højdepunkt er disse tendenser tydelige. Hans »Tider og Typer, Af dansk Aands Historie « er helt ud i sin titel talende omend ikke så eksplicit som hans indledning. 
Videnskabeligt set er mit Arbejde intet mere end en Tolkning af den danske Aands Historie gennem dens Typer. Kunstnerisk er det intet mindre end et Fors $\emptyset \mathrm{g}$ paa at skrive dens Epos.

(Tider og Typer, Erasmus 1, s. XXIX, Kbh. 1907).

Vilhelm Andersen opsummerer foreløbigt dannelsestraditionens erkendelser. I sit anlæg rummer »Tider og Typer« dog et idealistisk fors $\varnothing \mathrm{g}$ på at behandle historien historisk: Den danske Ands historie.

Anderledes ser det ud i Vilhelm Andersens hovedværk: „Illustreret Dansk Litteraturhistorie« bind II-IV. Her træder selv åndshistorien $\mathrm{i}$ baggrunden.

Efter eget udsagn har værket sin svaghed i det historiske og sit fortrin i det psykologiske. Arten af dets menneskeskildring træder klarest frem, hvor emnet er en person uden forfatterskab...

(Jørgen Elbek, Kritikkens genmæle, s. 14 in: Litteraturen i dag, Kbh. 1970).

Hos Vilhelm Andersen drejes analysen over i det psykologiske, i socialisationen. Som Elbek konstaterer, træder menneskeskildringen klarest frem, hvor emnet er en person uden forfatterskab. Det bærende i fremstillingen hos Andersen er hans solidaritet med de personer, han skildrer, konstaterer Elbek. Solidaritet med borgerlige forfattere $i$ en endnu ikke fuldt udviklet borgerlig tid. Det er derfor heller ikke så underligt, at Vilhelm Andersens litteraturhistories svaghed er dens manglende historiske forståelse af sit stof. I organiseringen af litteraturhistoriens stof slår det psykologisk individualiserende grundlag helt ud i storstrukturen. Dannelsestraditionens individualistiske udformning opløser i 2. bind helt perioden som historisk kategori, og Vilhelm Andersen går som konsekvens heraf over til at periodisere på individuelle forfatterskaber. I 1700-tallet delt op i Holbergs, Ewalds og Baggesens samtid. I 3. bind foretages den berømte og berygtede opde- 
ling af 1800-tallet i ti-år, der kombinerer dannelsestraditionens individualisme med positivismens statistiske mentalitet. Om man vil, kan man opfatte det som et forsøg på at forholde sig til visse overindividuelle historiske udviklinger.

Man kan kritisere dannelsestraditioen for dens uudviklede historiesyn. Men det er en logisk følge af dens socialisationsinteresse. Bredere sagt fremstår dannelsestraditionens historieløshed som en følge af dens karakter af borgerlig tænkning. Denne tradition forlænger erfaringer fra borgerskabets kamp mod feudalismen til en gyldighed af almen karakter. Den gør historiske erfaringer til vilkår.

Disse vilkår er den borgerlige socialisations vilkår. Vilhelm Andersen betragter forfatterskaberne som realiseringer af det personlige og derefter det nationale. Ud af hele hans flere tusind sider lange historie kommer borgeren slentrende.

Der er selvfølgelig arbejdsmæssige grunde til, at han »kun« har skrevet de sidste tre bind af »Illustreret dansk litteraturhistorie «. Alligevel er det påfaldende og næppe tilfældigt, at han begynder ved Holberg, og at han først rigtig får orden på sin fremstilling, da han kommer til romantikken. Det er ham selv delvist bevidst. Han siger:

Det attende Aarhundrede er den danske Kulturs første litterære Periode ... (bd. 2, s. 1)

Som det er omtalt i Indledningen til dette Kapitel, er det attende Aarhundrede den danske Kulturs f $\varnothing$ rste egentlige Litteraturtid / . . / Først med ham (Holberg, J. H.) træder denne Litteratur (den »almindelige«, J. H.) frem som selvstændig Organ for Aandslivet efter Kirken og Universitetet, der endnu i det foregaaende Aarhundrede havde været dets næsten eneherskende Udtryk. (bd. 2, s. 356)

Disse konstateringer er på sin vis naturligvis rigtige, men samtidig udvides udsagnene til at blive en generel karakteristik af, hvad litteratur er, de er derfor samtidig en afvisning af den ikke borgerlige litteratur. Vilhelm Andersen lader Carl S. Petersen 
gennemføre programmet på den ikke borgerlige litteratur, hvad der viser sig at være en umulighed. Den stadige fremhævelse af kvalitetsforskellen mellem Vilhelm Andersens og Carl S. Petersens fremstilling er da i virkeligheden blot en understregelse af de begrænsninger som ligger i selve metoden. Det er en patetisk oplevelse at læse første bind af »Illustreret Dansk Litteraturhistorie « og følge de heroiske fors $\varnothing g$ på at få ideen om den personlige (humane) og folkelige (nationale) dannelse til at fungere på århundreder, der har en ganske anden samfunds- socialisations- og litteratur-opfattelse. Dette er tydeligt overalt hos Carl S. Petersen netop, fordi de perioder han behandler stofligt sætter hans metodes svagheder i relief. Hele litteraturproduktionen fremstilles i hans bind, hvis man skal sige det kort, som en prolog til det egentlige gennembrud for den danske litteratur. Under håbløse betingelser kæmper forfatterne sjældent med held for at gøre det danske sprog til et litteratursprog.

2.

Et eksempel på dette er Kingo, der ifølge Carl S. Petersen yder en fremragende men dog ikke ganske vellykket indsats. Fremstillingen af ham hviler næsten udelukkende på salmerne, mens der kun afsættes ganske få sider til hans lejlighedsdigtning. Der er ganske korte omtaler af nogle af Kingos inskriptioner, og der citeres af hans vægtervers og hans hyldestdigtning til kongen som national helt. Dèr hvor Carl S. Petersen går uden for salmerne, der fremhæves, fordi de evner at tale alment til enhver generation, det nationale. Derimod er Kingos sammenfatning af det feudale samfundsbillede ikke behandlet. Hans store digt Hosianna nævnes ved titlen, mens jeg ikke har kunnet finde en omtale af digtet om Odense Hospital. Men netop i disse digte er sammenfatningen af hele Kingos indsats, der sprænger dannelsestraditionens kunstopfattelse.

Digtet om Odense Hospital hedder i sin helhed:

„De fattiges udj Odense Hospital allerinderligste og underdanigste Suk og Søgning hos vor allernaadigste Herre og Konge. « 
Som man kan se allerede af titlen er der altså tale om et bønskrift til Christian d. V., fra ca. 1682.

Herudfra er hele digtet bygget op i en række mere eller mindre faste afsnit, der følger digtets aleksandrinere, der hører sammen i skjulte 4-linjede strofer. I introduktionen undskylder Kingo, at han udgyder »vand og sjæle-ve« med at de fattige og syge $\mathrm{i}$ hospitalet ellers »må gå deres vej på verdens sti.« Derefter følger digtets hovedafsnit, som er en beskrivelse af de syge og fattige som dyr, der er lænket til jorden af korsets lænker. Den reelle baggrund for situationen på hospitalet præciseres som lejetroppernes indkvartering på hospitalets jorder, og endelig slutter digtet med, at Kingo lægger sig for kongen og for Guds stol i håb og måske forvisning om, at der kan findes en udvej.

Lad mig karakterisede to hovedtræk i den oplevelse af verden, som digtet lægger frem.

De fattige og de syge beskrives med en overordentlig realisme. Man kan ved at sammenligne med listerne over lemmerne i Kingos tid som administrator næsten pege de enkelte ud som han beskriver: vattersottige, gale, syfilitikere etc., men denne konkrete syge eller fattigdom får sin fortolkning. Døden tygger på hjertet af den, der ikke selv kan spise, og de gale beskrives som dyr der er tynget til jorden, sygdommen får sin metafysiske dimension, fordi den ikke blot er sig selv, men samtidig er "senerne i korsets kæde«. Tolkningen af det konkrete tillægger det en større betydning end lidelsen, nemlig lidelsens himmelske dimension. Til den konkrete lidelse føjes der et aspekt, der giver lidelsen en dybere mening, ud over at være lidelsen i den konkrete forstand er den også lidelsen ved at leve $i$ syndens og dødens perspektiv. Den syges krop er med Foucaults ord dobbelt: på den ene side har den sin jordiske dimension, på den anden side er den et udtryk for en ikke jordisk dimension. De syge har derfor også nåden behov $\mathrm{i}$ begge dimensioner. På tilsvarende måde kan man finde $\mathrm{i}$ digtet, at den der skal udløse lemmerne af deres situation har en tilsvarende dobbelt krop. Kongen (der var god til parforcejagt, men iøvrigt manglede kundskaber) er ikke blot en enevældig monark, han er også Christian den 
fromme. Han repræsenterer også kontinuiteten i embedet og er som sådan under Guds direkte beskyttelse. I fortolkningen af kongen ser man en klassisk lutheransk ortodoks tankegang, udover at være en konkret konge, er han også den der fører sværdet for Gud i verden. Det er ikke så mærkeligt at Kingo siger:

Forlad mig at jeg må mig ned i støvet bøje o konge for din stol, og himlens store $\emptyset j \mathrm{j}$

Også når man betragter magtens reprasentant er det konkrete på én gang en verdslig magt og en metafysisk magt. Det konkrete repræsenterer ikke blot sig selv, men også selve guds myndighed. Kongens nåde er ikke blot en forbedring af lemmernes situation på Odense Hospital, men den er også »et plaster af din hånd til JESU sår«. I kongens person falder den verdslige og den kirkelige magt sammen, men det er ikke det samme som at den guddommelige nåde og den verdslige nåde falder sammen.

Kingos bønskrift fik ingen følger. Lejetropperne vedblev med at være stationeret på hospitalets gods, og den del af lemmerne blev drevet ud af hospitalet. Der har åbenbart været mere brug for sværdet end for nåden til at holde synden $i$ ave. Kongens hærreform har været vigtigere end fattigforsorgen.

Hvis jeg et $\varnothing$ jeblik vender tilbage til opfattelsen af lidelsen, så understregede jeg, at der var en konkret sanselig lidelse, og at denne samtidig var en lidelse med en metafysisk dimension. Derimod er der i beskrivelsen af lemmernes lidelser ikke en indre dimension. Lidelsen er naturligvis konkret, men den får betydning ikke ved den betydning den har for det enkelte lem i hospitalet, men ved sin metafysiske dimension. Der findes ingen psykisk bearbejdelse af lidelsen. De vilkår, under hvilke lemmerne lever, peger mod det hinsides. Derfor er Kingos beskrivelse af lidelsen heller ikke et forslag til eller en appel om at fjerne lidelsens årsager, der er intet socialreformatorisk $i$ hans opfattelse. Lidelsen såvel som nåden får sin betydning gennem sig selv, ikke ved sin sociale betydning.

Hvis man går uden for teksten bliver det helt klart. Her ser 
man, hvordan den bestemte tolkning af forholdet mellem den konkrete lidelse og fortolkningen af lidelsens metafysiske aspekt giver sig udslag i bestemte forholdsregler, der har den ideologiske tolkning som handlingsanvisning, mens en social tolkning overhovedet ikke er til stede. Tydeligst er det i historien om Maren Spillemands, der indespærres, ikke på grund af fare for smitte eller voldelighed, men fordi hun er det ekstreme udtryk for bruddet med den ideologiske tolkning af det konkrete. I hendes tilfælde f $\varnothing$ res den ideologiske kamp ved at hun isoleres fra de andre lemmer, fordi man må formode at hun er besat af djævelen. Og som vi har set, tolkes forholdet til det metafysiske direkte igennem det sanseligt konkrete. Altså når der raser en kamp i hende mellem satan og Gud, så må hun være den det er mest nærliggende at isolere, hun er farligere end de voldkomme eller smitsomme.

Eller det andet eksempel: indretningen af sygestuen viser hvorledes lidelsen tolkes direkte ind i den metafysiske orden. De syge ligger under alteret, fordi det metafysiske og det fysiske falder sammen. Tydning og sansning er et.

Med denne viden om forholdet mellem det fysiske og det metafysiske i Kingos ideologi, som vi har set i den praktiske adfærd i hospitalet, nærmer vi os også forklaringen på den specielle digteriske kunnen som Kingo udfolder, idet hans evne som digter udfolder sig i dobbeltheden af på en gang konkret og metafysisk perspektiv. Barokkens ordavl og, i anførselstegn, tautologiske beskrivelser, barokkens dobbeltmetaforer făr deres forklaring og trækker deres kraft netop fra dobbeltheden i dens fortolkning af verden. Det kan følges hele vejen igennem digtet.

Kingo græder en strøm af »vand og sjæleve«, døden tygger på benradens hjerte, de syge jamrer som bæster (uden for guds nåde), Christian er den femte og fromme, en vånder sig for ve og sidesting, de fattige får $\varnothing \mathrm{log}$ mad, men de får også olie og vin for deres sjælesår, og Kingo lægger sig for kongens stol og for Himmelens store $\varnothing j \mathrm{je}$. Den specielle form, Kingos digtning antager og hans originalitet i forhold til den borgerlige digtning, udspringer af det specielle forhold han har til virkeligheden og 
dens dimensioner. Den er derimod ikke udtryk for en speciel følsomhed eller en særlig evne til at indleve sig i de fattiges situation, andet end netop som repræsentativ lidelse.

Den borgerlige litteraturhistorieskrivning undskylder og beklager Kingos smagløshed og hans makabriteter:

Det meget Græderi kan flyde helt ud i det vamle $\mathrm{i}$ en linje som »Jeg laver til hans (Jesu) Saar et Grædebad«, ligesom det kan knibe med at holde sig på det smagfuldes grænse, når han går over til Fordybelsen i Makabriteter og forestiller sig "Gravens Vraa, hvor Ormen da skal vrimle i min Hud«.

(Carl S. Petersen, s. 945)

mens det er sådan at

højst når han netop, hvor Tids- og Stilpræget gør sig mindst gældende; da taler han til ethvert Slægtled med enkle, stærke ord. (samme sted).

Carl S. Petersen taler om Kingos kontrastrige temperament, og i beskrivelsen af Kingo er der en besynderlig disharmoni mellem den selvkritiske, konstant angergivne kristne, og på den anden side, den krakilske aggressive udadvendte bisp. Kingo opfører sig i litteraturhistorien som en voldsom men dog akceptabel borgerlig.

\section{3.}

Dannelsestraditionen har været overordentlig stabil. Som litteraturteori er den udviklet i slutningen af 1800-tallet og som grundlag for skolepolitikken i begyndelsen af 1900-tallet. Men de erfaringer, der danner grudlaget for hele retningen er gjort af de tyske og danske romantikere fra begyndelsen af 1800-tallet. Først i 1960'erne er afviklingen af dannelsestraditionen slået igennem. Den har således holdt sig i 150 år i forskellige former, lige så længe som den lutherske ortodoksi, og der går ingen vej uden om en gennemgribende kritik af den. 
Afviklingen af dannelsestraditionen finder, så vidt jeg kan se, næring af to sociale og kulturelle strømninger. Dels af den kulturradikale tradition, dels af studenteroprøret fra 1968 og fremad.

Kulturradikalismen vokser sig stærk i opgøret med den kolde krig. Den formulerer på et til tider elitært grundlag et opgør med den borgerlige ideologi ved sin mistillid til det politiske establishment, sin mistillid til sproget og inden for litteraturkritikken sin mistillid til dannelsestraditionens sene former, især som de kommer til udtryk i biografismen. Det litterære værk kommer i centrum og dermed de metodespørgsmål, som læsningen af de litterære tekster rejser. Dette sker som oftest på bekostning af den historiske læsning. Tematisk analyse og kvalitetsvurdering står i centrum. Som et, til tider uønsket, resultat følger et angreb på den historiske læsning.

I nyradikalismen og dens formulering som nykritik inden for litteraturforskningen ligger opgøret med dannelsestraditionen fuldt udviklet, da studenteroprøret satter ind i slutningen af 60 'eme. Studenteroprørets bidrag til kritikken af dannelsestraditionen er det institutionaliserede opg $\phi$ r. Den stribe af reformer inden for de højere uddannelser, som følger i studenteropr $\emptyset$ rets kølvand, presser dannelsestraditionen ud af de positioner, som den har erobret fra begyndelsen af 1900-tallet og frem til 60'erne. F $\varnothing$ rst og fremmest er der her tale om en udvidelse af tekstbegrebet $o g$ en gennemf $\varnothing$ relse af metodefriheden i praksis. At studenteroproret er istand til at følge radikalismens teoretiske kritik op med en kritik i praksis hænger formodentlig sammen med den bredere rekruttering til de højere uddannelser og etableringen af nye mellemlag under højkonjunkturen i 60'eme. Men også her forløber opgøret således, at det historiske synspunkt trænges tilbage, og netop studenteroprøremes synspunkter slår igennem $i$ den vejledning for undervisning i gymnasiet, der kommer i 1971. Den repræsenterer ikke blot dannelseskompleksets endelige opløsning, men er også et omfattende angreb på den historiske læsning. 
4.

Vejledning og retningslinjer for undervisningen i gymnasiet (Direktoratet for gymnasieskolen og HF, 1971) som blev udsendt $i$ forbindelse med bekendtgørelsesændringen er et katalog over synspunkter, metoder og stof som anvendes $\mathrm{i}$ undervisningen, uden nogen form for ordnende plan, men med et stort fremskridt, nemlig etableringen af den totale metodefrihed. Studenteroprørets opg $\varnothing \mathrm{r}$ med den borgerlige dominans inden for undervisningen er her ført så langt, som det kan gøres på et pluralistisk grundlag.

Man kan se det ved at følge vejledningens anvisninger for den historiske læsning. Den historiske læsnings svage placering er et direkte udtryk for studenteroprørets betydning.

En sådan revidering af den historiske læsning må i første instans rette sig mod den førborgerlige tekstmasse. Den historiske læsning koncentreres om tre områder, der vel at mærke i den samlede beskrivelse i vejledningen kun udg $\varnothing \mathrm{r}$ en meget lille del. For det første, og som det vigtigste, har vi tiden fra 1800 til idag (hvor er det det er set før?), hvor hovedvægten lægges på tiden efter 1920. »Dette motiveres med, at man ud fra en tættere læsning skal søge at danne sig et sammenhængende billede af vor egen tid, således at elevernes samtids- og selvforståelse $\phi$ ges«. Det andet område er behandlingen af en periode fra før 1920. Endelig opereres der $\mathrm{i}$ vejledningen med et tredje område der består af et mindre antal tekster fra tiden før 1800. Og herom hedder det: »Her er det historiske perspektiv indsnævret (vejledningens egne ord!) således at man kun behandler et enkelt emne, f.eks. en genre eller et tema«.

Om valget af tekster f $\varnothing \mathrm{r} 1800$ hedder det senere: $\gg$ Valget af tekster bestemmes her af et overordnet synspunkt af $i k k e$-historisk art« (min fremhævelse), og der nævnes derefter en række forslag til hvordan man kan bære sig ad med at behandle tekster før 1800 uhistorisk. Man kan perspektivere dem ved at sammenstille dem med senere tekster, hvor der lægges stor vægt på tekster efter 1800 , eller man kan »sammenstille tekster frit " og det understreges, at en sådan prioritering ikke er mindre vigtig end 
den historiske læsning. Hvis man f.eks. ønsker det, kan man læse et forfatterskab, hvor vægten lægges på selvrealiseringen i forfatterskabet.

Man kan altså, måske lidt firkantet, konkludere, at vejledningen $\mathrm{i}$ beskrivelsen af læsemuligheder i »perioden « f $\varnothing \mathrm{r} 1800 \mathrm{læg}$ ger op til, at man kan behandle teksterne uhistorisk. Dette understreges bl.a. af, at hvor der tages tekster op i en større sammenhæng, anvender vejledningen forestillinger fra den borgerlige digtnings historie som struktureringsprincip, f.eks. selvrealiseringen inden for et forfatterskab.

$\mathrm{Nu}$ er vejledningen jo kun en vejledning og må formodes at være formuleret relativt pluralistisk, for at de fleste dansklærere kunne leve med den nye bekendtgørelse, men uanset dette går gennem hele vejledningen tendentielt en borgerlig sans for den borgerlige digtnings værdier, og på de ikke borgerlige tekster anlægges borgerlige synsvinkler. Tidsmæssigt afgrænses der til den borgerlige epoke, idet der dog kan laves udblik til borgerskabets første kampperiode i slutningen af 1700-tallet. I metode og synsvinkler følger vejledningen linjer, der er udviklet af den borgerlige litteratur og den litteraturkritik, der er udviklet i tilknytning hertil. Den kunstdigtning der er produceret i f $\varnothing$ rborgerlige perioder ses i den borgerlige litteraturs bakspejl.

\section{5.}

Den historieløse er mest fortidsbundet. Det ser man i vejledningens forhold til historien. Uden viden om hvad den gør, gør vejledningen noget andet end den tror den gør. I sit kvantitative opgør med den borgerlige tradition, slæber vejledningen alle den borgerlige litteraturkritiks forestillinger med sig. Ved en nærmere læsning af vejledningen får man en klar fornemmelse for, hvorfor det er vigtigt at holde historien fast som den dimension, hvorudfra alt forstås. Det vigtige i at arbejde med historien som dimension fremstår tydeligt ved en betragtelse af den totale forvirring, der hersker i vejledningens endeløse opremsning af, hvad man også kan gøre. Og det er naturligvis altid vigtigt at have mange muligheder, vel at mærke hvis disse muligheder betyder 
noget. Men i vejledningen står alle de mange muligheder som forskelsløse veje, man kan gå. Vejledningen vil kort sagt ingen ting. Og i det historiske, som $\mathrm{i}$ vejledningen er skubbet ud i et hjørne, får man en komprimeret udgave af den borgerlige historieopfattelse, helt uden dannelsestraditionens sans for det historiske, men selvfølgelig også uden dannelsestraditionens klaustrofobiske univers.

En vigtig grund til at gå så historisk til værks er, at kun denne fremgangsmåde gør de tekster man arbejder med forståelige. Det er tydelig i Kingos tilfælde, som jeg har søgt at vise det overfor. Men det er også nødvendig for at forstå tekstens sociale funktion. Dette turde være argumenter som er ved at blive alment akcepteret, men det er ikke argumenter, der i sig selv forklarer, hvorfor man overhovedet skal beskæftige sig med ældre perioder. Som Henning Salling Olesen siger: »Historisk bevidsthed udvikles ikke af at læse tekster fra ældre perioder. Det er vel idag en »banalitet « (En historisk orienteret didaktik, in: "Historien i dansk « 1978), men det er også en banalitet, at den heller ikke udvikles af at lade være. Det understreger blot, at det er helt nødvendigt at gøre sig klart, hvad man vil med den historiske læsning, så først kan man tage stilling til, hvordan man vil behandle det historiske stof.

Ved kun at tage tekster op fra den borgerlige periode garanterer man kun, at man holder sig inden for den borgerlige tankeverden. Man garanterer, at man igen og igen finder de samme grundlæggende tankefigurer, som man selv gentager i sit daglige liv i det borgerlige samfund. Man får altså gennem en beskæftigelse med tekster fra det borgerlige samfunds epoke, lejlighed til at genfinde og se kritiseret bestemte dybtliggende strukturer i sin egen verdensopfattelse, men man finder også hele tiden lejlighed til en kritik som er immanent $i$ forhold til de borgerlige tankeformer. Man vil aldrig opleve borgerligheden som noget, der ikke kommer sagen ved. Alligevel er det her den vigtigste kritiske funktion $\mathrm{i}$ forhold til de borgerlige tekster er, nemlig den, at de fremstår som noget historisk produceret, der ikke på nogen måde kan betragtes som en selvfølgelighed. Hvad er da bedre 
til at udstille borgerligheden som historisk, som noget socialt men ikke naturgivet, end netop tekster, der er produceret f $\varnothing \mathbf{r}$ den borgerlige epoke. Det bedste argument for disse tekster, forsåvidt man beskæftiger sig historisk og ikke idealistisk med dem, er da netop, at det er ikke borgerlige tekster, og at de er fremmede for den der skal tilegne sig dem. Ved selve deres eksistens er disse tekster et angreb på den borgerlige selvforståelse, og de rejser derfor et krav om et ikke selvspejlende forhold til historien. De formulerer gennem deres eksistens et krav om indsigt i det fremmed-psykiske og -sociale på en så radikal måde, at de bliver uforståelige, hvis man betragter dem ud fra borgerlige synsvinkler. Der ligger et emancipatorisk perspektiv $i$ at beskæftige sig med disse tekster, som der altid gør, i at opleve noget anderledes som anderledes end sig selv. Deri ligger ikke blot, at der åbner sig en mulighed for at etablere en kritikposition som tager sit udgangspunkt udenfor borgerligheden, men der ligger også den frihed, der kan få folk til at elske skildpadder af andre grunde end, at der kan laves skildpaddesuppe af dem.

I kritikken af dannelsestraditionen har det været overset at dens sande styrke ligger $i$, at den har et dannelsesideal. Den giver ikke blot en bestemt, som det nu er tydelig, fordrejet opfattelse af historien, den giver også et dannelsesmæssigt ideal, som det har været vigtigt at få gjort op med, men som ikke må medføre at beskæftigelsen med litteraturen ophører med at forholde sig til socialisationsprocessen, som individets og kollektivets orientering i verden. Det er indlysende, at det ikke bliver magistre i dansk, der kommer til at afgøre, hvorledes den individuelle og kollektive dannelse og socialisation kommer til at foregå nu, da de borgerlige dannelsesidealer er inde $\mathrm{i}$ deres endelige sammenbrud, men det er lige så klart, for mig at se, at hvis ikke dannelsesperspektivet set under en historisk synsvinkel bliver centralt, så er der ingen grund til at opretholde de institutioner der er vokset op omkring den litterære produktion inden for de sidste par hundrede år. 